Génét. Sél. Evol., 1985, 17 (2), 191-200

\title{
Nonhistone chromosomal protein patterns in leucocytes of inbred chicken and their crosses
}

\author{
Sylvia FRITSCHI *, N.U. BOSSHARD ** and G. STRANZINGER \\ Federal Institute of Technology \\ Institute of Animal Production Section Animal Breeding \\ $\mathrm{CH}-8092$ Zurich, Switzerland
}

\begin{abstract}
Summary
The patterns of nonhistone chromosomal proteins (NHCP) soluble in $0.3 \mathrm{M} \mathrm{NaCl}$ of pure inbred chicken lines and their crosses have been analyzed. Within pure bred lines there is little variation of the NHCP patterns, but within cross and between different pure bred lines distinct differences can be detected. Possible practical applications of the analysis of NHCP patterns in animal production are discussed.
\end{abstract}

Key words : Nonhistones, chicken, leucocytes.

\begin{abstract}
Résumé
Electrophorégrammes de protéines chromosomiques non histoniques (du type 0.3 M NaCl) des leucocytes de lignées consanguines et de leurs croisements chez la poule
\end{abstract}

Les profils électrophorétiques de protéines (NHCP) chromosomiques non histoniques (du type 0,3 M NaCl) ont été établis chez la poule dans des lignées consanguines et leurs croisements. Les profils NHCP des lignées consanguines elles-mêmes varient peu. Cependant, une différence très nette apparaît pour les croisements et entre les différentes lignées consanguines. Les applications pratiques des profils électrophorétiques sont discutées pour la production animale.

Mots clés : Protéines non histoniques, poulets, leucocytes.

Present address :

(*) Institute of Toxicology, Federal Institute of Technology and University of Zurich, CH-8603 Schwerzenbach, Switzerland.

(**) Department of Pediatrics, University of Zurich, CH-8032 Zurich, Switzerland. 


\section{Introduction}

Inbred lines are a useful tool in animal breeding and genetic studies, since by continuing inbred pairing the homozygosity increases from one generation to another. We have chosen inbred chicken lines that show distincts differences in genotype (AbPlanalp et al., 1981), phenotype and behaviour to study patterns of nonhistone chromosomal proteins (NHCP) in leucocytes. Part of the nonhistone proteins are considered to be involved in gene regulation (Allfrey, 1974; PaUl \& GilMOUR, 1975 ; CHIU \& HNILICA, 1977; Horst et al., 1981) and have been found to be species-specific (CHIU \& HNILICA, 1977 ; Bosshard et al., 1982). In thymus tissues of cattle, differences in the NHCP patterns have been found between individuals of the same breed (BOSSHARD \& STRANZINGER, 1983) and family studies of cattle suggest that NHCP patterns in leucocytes can be used as genetic markers (BosshARD, unpubl. data). NHCP patterns may serve for the biochemical characterization of inbred chicken lines, leading eventually to correlation of certain characteristics in the NHCP patterns with phenotypical traits of the animals.

\section{Material and methods}

White Leghorn chicken inbred lines $71,75,77,79$ (HAgger \& STEIgER-STAFL, 1982) and their crosses $71 \times 79,71 \times 75,75 \times 77$ and $77 \times 79$ from our experimental station were raised and kept under indentical conditions. Blood samples $(20-25 \mathrm{ml} /$ animal) were collected from the wing veins of cocks. To avoid coagulation, the needles and syringes were haprinized (Heparin, $5000 \mu / \mathrm{ml}$, Seromed, Munich, West Germany). The samples were transported on ice to a cold room $\left(4^{\circ} \mathrm{C}\right)$ and stored overnight.

\section{A. Isolation of Leucocyte Nuclear Proteins}

All steps of protein extraction were conducted at $4{ }^{\circ} \mathrm{C}$ in the cold room. Blood samples were centrifuged in two $10 \mathrm{ml}$ portions for $30 \mathrm{~min}$ at $3,000 \times \mathrm{g}$ (Junior 3000, Haereus Christ, Osterode, West Germany). The supernatant was removed and discarded. The leucocyte fraction, lying on top of the erythrocyte sediment, was collected by a pipette, washed by dispersing it in $10 \mathrm{ml}$ of isotonic $\mathrm{NaCl}$-solution (Isoton II, Coulter Electronics $\mathrm{GmbH}$, Krefeld, West Germany) and centrifuged for $10 \mathrm{~min}$ at $1,500 \times \mathrm{g}$. The sediment was dispersed in $10 \mathrm{ml}$ of $150 \mathrm{mM} \mathrm{NH} \mathrm{NH}_{4} \mathrm{Cl}$, kept in this solution for $20 \mathrm{~min}$ and centrifuged for $10 \mathrm{~min}$ at $1,000 \times \mathrm{g}$. This procedure, which removes erythrocytes contamination (BOYLE, 1968) was repeated twice exposing the cells to $\mathrm{NH}_{4} \mathrm{Cl}$ for $20 \mathrm{~min}$ and twice fort $10 \mathrm{~min}$. Afterwards the sediment was dispersed in $10 \mathrm{ml}$ of solution $\mathrm{C}(80 \mathrm{mM} \mathrm{NaCl}$, $20 \mathrm{mM}$ EDTA-Na*, adjusted to $\mathrm{pH} 8.0$ with $1 \mathrm{M}$ Tris*), two drops (ca. $50 \mu 1$ ) of Zaponin (Coulter Electronics Ltd, Harpenden, GB) were added and, after shaking, the samples were kept in this solution for two min. This procedure yielded a purified leucocyte nuclear fraction. After ading $10 \mathrm{ml}$ of solution $\mathrm{C}$ and

(*) EDTA-Na = Ethylenediaminetetraacetic acid disodium salt.

Tris $=$ Tris (hydroxymethyl)-aminomethane. 
centrifuging for $10 \mathrm{~min}$ at $1,000 \times \mathrm{g}$, the Zaponin was washed out of the sediment by subsequently resuspending it in solution $\mathrm{C}$ and then in $120 \mathrm{mM} \mathrm{NaCl}, 0.5 \mathrm{mM}$ EDTA-Na, adjusted to $\mathrm{pH} 8.0$ with $1 \mathrm{M}$ Tris, and centrifuging for $10 \mathrm{~min}$ each at $1,000 \times \mathrm{g}$. The nuclei were then dispersed in $25 \mathrm{ml}$ of $300 \mathrm{mM} \mathrm{NaCl}, 10 \mathrm{mM}$ Tris$\mathrm{HCl}(\mathrm{pH}$ 7.2), $0.25 \mathrm{mM}$ EDTA-Na and kept on a magnetic stirrer for $60 \mathrm{~min}$. By this procedure nonhistone proteins were extracted from the nuclei. They were separated from the remaining nuclei by centrifugation for $15 \mathrm{~min}$ at $17,500 \times \mathrm{g}$ (Junior 15000, Haereus Christ, Osterode, West-Germany).

The supernatant, containing soluble nuclear proteins (BossHARD, 1979 ; BOSSHARD \& STRANZINGER, 1983) was dialyzed four times against 20 to 50 times its volume of $0.5 \mathrm{mM}$ EDTA-Na, adjusted to $\mathrm{pH} 8.0$ with $1 \mathrm{M}$ Tris, for at least 8 hours, centrifuged for $15 \mathrm{~min}$ at $17,500 \times \mathrm{g}$ and the supernatant was freeze-dried.

\section{B. Determination of DNA and Protein Concentrations}

DNA and protein concentrations were determined as reported previously (Bosshard et al., 1982) by measuring the optical density (OD) of the samples at $250 \mathrm{~nm}$ and $260 \mathrm{~nm}$ with a Perkin Elmer 550 spectrophotometer.

\section{Polyacrylamide Gel Electrophoresis (PAGE)}

Electrophoresis in 7.5 p. 100 SDS*-polyacrylamide gels was carried out according to procedures of LAEMmLI (1970) in vertical slabs $1.5 \mathrm{~mm}$ thick in a Bio-Rad 220 chamber (Bio-Rad, Richmond, CA, USA). The lyophilized samples were dissolved in sample buffer (SDS 1 p. 100 , urea $6 \mathrm{M}$, mercaptoethanol 1 p. $100(\mathrm{v} / \mathrm{v}), \mathrm{NaH}_{2} \mathrm{PO}_{4}$ $10 \mathrm{mM}$, adjusted to $\mathrm{pH} 7.2$ with $\mathrm{NaOH}$ ) according to Weber \& OsBorN (1969) at a concentration of $2 \mathrm{mg}$ protein $/ \mathrm{ml}$. Electrophoresis at $220 \mathrm{~V}$ (constant) was stopped after the Bromphenol Blue marker of the sample had reached the bottom of the gel (about 90 to $110 \mathrm{~min}$ ). The gels were stained overnight in a solution containing 0.025 p. 100 Coomassie Blue R-250, 50 p. 100 methanol and 7 p. 100 acetic acid, destained in 5 p. 100 methanol with 7 p. 100 acetic acid, and scanned at $570 \mathrm{~nm}$ with a densitometer (Quick Scan Junior TLC, Desaga, Heidelberg, West Germany).

Densitometric scans were replotted on a digitizer HP 9874 A (Hewlett Packard, Fort Collins, USA). Areas under prechosen sections of a densitometric scan were measured and expressed as percent of the total integral by a desktop computer (HP 9845 B) and re-drawn on an XY-plotter (HP 9872 B).

\section{Results}

\section{A. Reproducibility of the NHCP Extraction Method}

Blood samples of the same cock were taken 3 times at intervals of one week and NHCP's were extracted from the leucocytes to test the reproducibility of the

(*) SDS = Sodium dodecyl sulfate. 
preparation method (fig. 1). The 3 densitometer scans show only small variations in relative height of peaks \# 4,6,8, and 11 . The poor congruence of the fast moving proteins is partly explained by different running speeds of the samples. Integrals of the areas of 4 chosen prominent peaks are shown in table 1; values are given in percent of the total integrals.

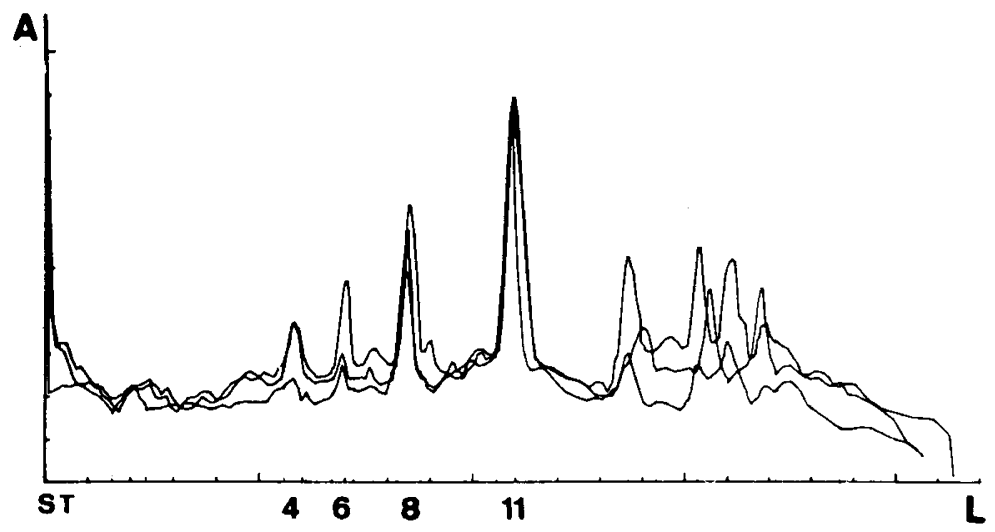

FIG. 1

Reproducibility of the NHCP Extraction Method.

Répétabilité de la méthode de l'extraction des NHCP.

Electropherograms of 3 independent samples of the same cock (inbred line 71). 7.5 p. 100 SDS-PAGE, start left ; \# 4 to 11 : Peak \# ; A : Optical density $(\lambda=570 \mathrm{~nm})$; L : Running distance.

Electrophorégramme de 3 échantillons indépendants d'un même coq (lignée consanguine 71). 7,5 p. 100 SDS-PAGE, start gauche; \# 4 à 11; \# numéro des pics; A : Densité optique $(\lambda=570 \mathrm{~nm}) ; L$ : Distance parcourue.

TABLE 1

Integrated Peak Areas of Peaks \# 4, 6, 8, and 11 .

Surface intégrée des pics \# 4, 6, 8 et 11.

\begin{tabular}{c|c|c|c|c}
\hline $\begin{array}{c}\text { Peak \# } \\
\text { Sample }\end{array}$ & 4 & 6 & 8 & 11 \\
\cline { 2 - 3 } 1 & 4.14 & 5.27 & 9.49 & 12.22 \\
2 & 5.19 & 3.30 & 6.19 & 15.83 \\
3 & 1.56 & 1.41 & 5.19 & 17.17 \\
\hline & 3.63 & 3.33 & 6.96 & 15.07 \\
x mean & 1.87 & 1.93 & 2.25 & 2.56 \\
\hline SD & & &
\end{tabular}

Values are given in percent of total integral of each sample.

Les valeurs sont données en pourcent de l'intégrale totale de chaque exemple. 

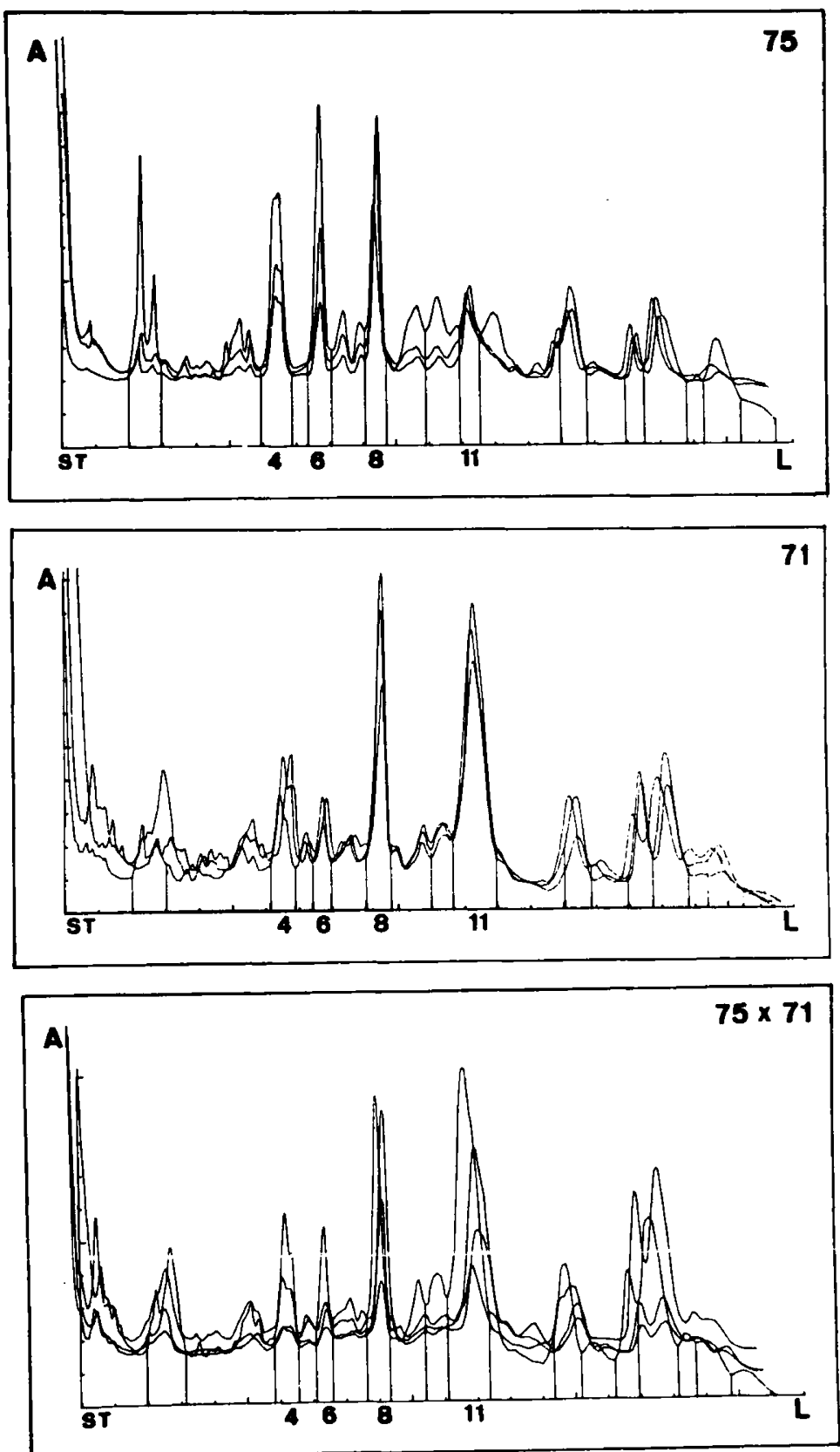

FIG. 2

NHCP-electropherograms of the inbred lines 71,75 and the crossline $71 \times 75$. Electrophorégramme NHCP des lignées consanguines 71,75 et des croisements entre les lignées $71 \times 75$.

7.5 p. 100 SDS-PAGE, start left; \# 4 to 11 : Peak \#; A : Optical density $(\lambda=570 \mathrm{~nm}) ; \mathrm{L}:$ Running distance.

7,5 p. 100 SDS-PAGE, start gauche; \# 4 à 11 : \# numéro des pics; A : Densité optique $(\lambda=570 \mathrm{~nm}) ; L$ : Distance parcourue. 


\section{B. Comparison of different inbred lines and their crosses}

NHCP-electropherograms of the 2 inbred lines 71,75 and the cross $75 \times 71$ are show in figure 2 ( $N=3$ for the purebred lines, $N=4$ for the cross). Peaks \# 4 and 6 are smaller in line 71 than in line 75 . Peak \# 8 shows high values in both purebred lines whereas peak \# 11 is high in line 71 and low in line 75 . The cross $71 \times 75$ values cover the whole range between values of lines 71 and 75 for all peaks considered above.

Four pure inbred lines were examined in all. The values for the integrated peak areas from inbred lines $71,75,77$, and 79 and from crosses $71 \times 79,71 \times 75$, $75 \times 77,77 \times 79$ are given in figure 3 , wherein the data of figure 2 are included. The most perceivable differences in peak size can be seen in peak \# 4, where line 77 shows the highest values, and in peak \#11, where lines $71,79,71 \times 79$, and $71 \times 75$ have evidently greater peak areas than the others. Although the range of variation is in some cases rather large, the mean peak sizes of the crosses are mostly between the values of the inbred lines from which they were derived.

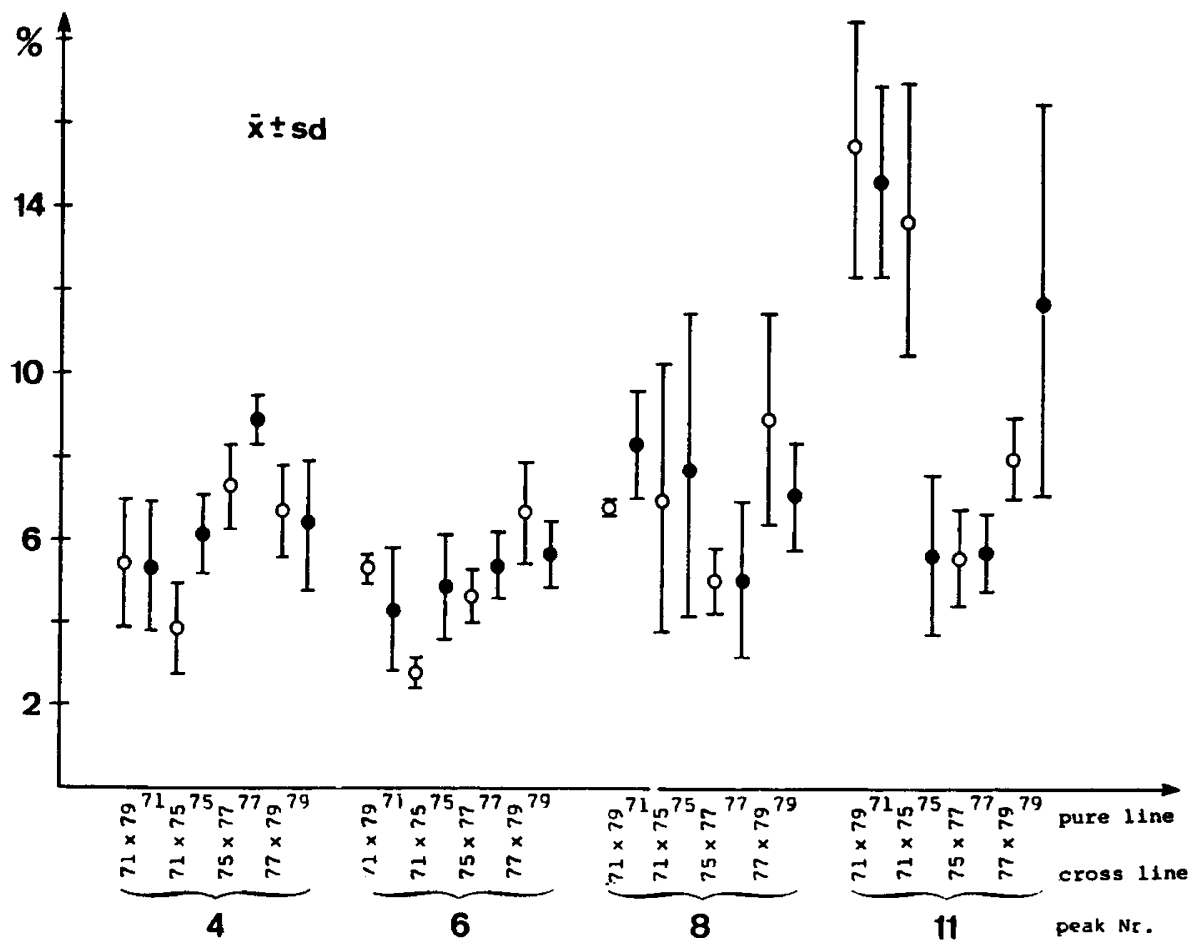

FIG. 3

Areas of Peaks \# 4, 6, 8, and 11 of 4 inbred lines and their crosses.

Surface intégrée des pics \# 4, 6, 8 et 11 de 4 lignées consanguines et de leurs croisements.

Dots : pure inbred lines; circles : crosslines.

Points : lignées consanguines pures; cercles : croisements. 


\section{Discussion}

Nonhistone chromosomal proteins (NHCP) form a heterogenous group of proteins with diverse biological functions such as enzymes, proteins affecting chromatin (and chromosome) structure and gene regulation (Johnson et al., 1974; PAuL \& Gilmour, 1975). The fact that NHCP's play an important role in gene activation has been generally accepted (Allfrey, 1974 ; Paul \& Gilmour, 1975 ; McGillivray, 1976 ; CHIU \& HNilica, 1977 ; Horst et al., 1981), but the group of gene regulating NHCP's has up to now hardly been characterized. The large number of nonhistone proteins found in different tissues and species may be responsible for this lack of knowledge; in addition to that it may be assumed that few copies of a protein would suffice for gene regulating activities (McGillivraY, 1977), making it doubtful whether they would be detected on a Coomassie Blue stained gel. On the other hand tissue - and species - specific differences in the patterns of extracted NHCP's do occur (ChIU \& HNilica, 1977; AnachKova \& Russev. 1977 ; Bosshard et al., 1982), therefore, they can be used as markers of a given genotype and/or state of gene expression.

The NHCP patterns of chicken leucocytes of 4 inbred lines and their crosses were examined. Within inbred lines there are relatively small differences of the protein patterns (expressed as protein peak numbers and sizes of electropherograms) whereas within crosses individual peak sizes vary mostly within the boundaries defined by their parental inbred lines.

If we stipulate that the NHCP pattern reflects a certain state of gene expression, one could assume that this pattern can be influenced by environmental factors. Since all donor animals in our experiments have been kept under identical conditions, the environmental influence should be similar on all animals considered; in fact a check on the reproducibility of the NHCP extraction method and on a possible timeinfluence shows that the pattern of one individual was constant over a period of 3 weeks, the time interval in which all the samples for this study were collected. Hence, differences observed in the NHCP patterns may be attributed mainly to different genotypes, and highly inbred lines have been chosen for the experiments to keep variations of genotypes within a given line on a low level.

The comparison between patterns of pure inbred lines and their crosses shows that some peaks $(\# 4,6,8,11)$ are prominent in all samples ; they may be characteristic for some cell functions of leucocytes. The data available up to now do not permit any correlation between certain protein bands and phenotypic traits. For example, lines 71 and 75 have the same genetic background and are the product of selection for high egg weight (HILfIKER-HENGARTNER, 1967); the only significant difference in their NHCP patterns is the size of peak \# 11. On the other hand, this peak is high, too, in line 79, which originates from selection for low egg weight; hence, any correlation of the size of peak \# 11 with egg weight can be ruled out in the lines concerned. Whether correlations between NHCP patterns of leucocytes and phenotypical traits such as egg weight are at all to be expected is a point open to argumentation, but we have shown that the NHCP patterns can be used as markers for the genetic status of any individual or inbred line. Such markers, which are quickly established, might be useful in animal production for checking the homo- 
geneity of an inbred line, the association of an individual of unknown origin to a certain breed or family, and, possibly, for the detection of bearers of congenital diseases. Since most of the biochemical markers presently explored have not shown any linkage to economically relevant traits of farm animals, new markers such as NHCP's could be useful for gene mapping, too.

\section{Acknowledgements}

The authors wish to thank Dr. C. HAgGer and Mrs. D. Steiger-Stafl for supplying the sample materials for this investigation.

Supported by ETH grant No. 0775/41-0735.5, 2461/41-0735.5. Request reprints from Prof. Dr. G. STRAnZinger, Institut für Tierproduktion, Gruppe Tierzucht, ETH-Zentrum, CH-8092 Zürich (Switzerland).

Received March 5, 1984.

Accepted October 26, 1984.

\section{References}

ALLFREY V.G., 1974. DNA-binding proteins and transcriptional control in procaryotic and eucaryotic systems. In : CAMERon I.L. \& Jeter J.R. (eds), Acidic Proteins of the Nucleits, 2-27. Academic Press, New York.

AnachKova B., Russev G., 1977. Evidence for the existence of a fraction of rat liver chromatin containing only a few specific nonhistone proteins and reduced amount of histone $\mathrm{H}$ 1. FEBS Lett., 81, 37-38.

Abplanalp H., Hagger C., Briles R., 1981. Genetic variation of blood groups in inbred lines of Leghorns, derived from a common base population. J. Hered., 72, 224-226.

Bosshard N.U., 1979. Einfluss von Ionen und Nitchthiston-Proteinen auf den strukturelle Zustand von isoliertem Kalbsthymus-Chromatin. Dissertation, Universität des Saarlandes, Math.-Naturw. Fak., Saarbrücken, West Germany.

Bosshard N.U., Morel P., Stranzinger G., 1982. Comparison of chromosomal protein patterns of thymus and liver in cattle, sheep, goats and pigs, J. Anim. Sci., 54, 248-257.

Bosshard N.U., Stranzinger G., 1983. Individual patterns of thymus nonhistone chromosomal proteins in cattle. Z. Tierz. Züchtgsbiol., 100, 296-303.

BoyLe W., 1968. An extension of the ${ }^{51} \mathrm{Cr}$-release assay for the estimation of mouse cytotoxins. Transplantation, 6, 761-764.

ChiU J.-F., Hnilica L.S., 1977. Nuclear nonhistone proteins : Chemistry and function. In : Li H.J., EckHARdT R.A. (eds), Chromatin and Chromosome Structure, 193-254. Academic Press, New York.

Hagger C., Steiger-Stafl D., 1982. Befruchtungsrate und embryonale Sterblichkeit bei hoch ingezüchteten Geflügellinien des Typs Weisse Leghorn in Reinzucht und Kreuzung. Schweiz. Landwirtsch. Monatshefte, 60, 269-275.

Hilfiker-Hengartner H., 1967. Die Veränderung der Blutgruppenfrequenzen im Laufe eines Selektionsexperimentes nach Anfangseigewicht. Z. Tierz. Züchtgsbiol., 84, 73-79.

Horst A., Rakowicz-Szulczynska E.M., Wiland E., 1981. Non-histone chromatin proteins during various stages of activity of immuno-competent cells. Mol. Cell. Biochem., 37, 3-12.

Johnson J.D., Douvas A.S., Bonner J., 1974. Chromosomal proteins. Int. Rev. Cytol., Suppl. 4, 273-361. 
LAEMmLI U.K., 1970. Cleavage of structural proteins during the assembly of the head of bacteriophage T. 4. Nature, 227, 680-685.

McGillivRaY A.J., 1976. Non-histone nuclear proteins as gene regulators ? Biochem. Soc. Trans., 4, 976-978.

MCGillivRay A.J., 1977. The analysis of chromatin non-histone proteins. In : BradbuRY E.M., JAVAHERIAN K. (eds), The Organization and Expression of the Eukaryotic Genome, 21-41. Academic Press, New York.

Paul J., Gilmour R.S., 1975. The regulatory role of non-histone proteins in RNA-synthesis. In : The Structure and Function of Chromatin, Ciba Foundation Symposium, 28 (new series), 181-198. Elsevier-Excerpta Medica-North Holland, Amsterdam-Oxford-New York.

Weber K., Osbron M., 1969. The reliability of molecular weight determinations by dodecylsulfate-polyacrylamide gel electrophoresis. J. Biol. Chem., 244, 4406-4412. 